DOI $10.31168 / 0440-4.8$

\title{
THE ORIGINS OF RUSSIAN SLAVIC STUDIES: SREZNEVSKY I.I.
}

\section{Abstract:}

The article is dedicated to one of the founders of Russian Slavistics, Izmail Ivanovich Sreznevsky (1812-80). Beginning his academic career with the study of Slavic folklore, he gradually expanded the sphere of his research. He wrote an essay on the history of Serbian-Luzhich literature, and then concentrated his attention on southern Slavs: their languages, old literature and paleography of old Slavic manuscripts. Teaching Slavic philology at Kharkov and St. Petersburg universities, he laid the foundations of academic Slavistics disciplines such as dialectology, mythology and ethnography. In 1846 he became the first doctor of Slavic-Russian philology and brought up a whole generation of brilliant scholars of Slavistics. For his scientific merits he was elected a full member of the Imperial Academy of Sciences and for many years was the editor-in-chief of the "News of the Department of Russian Language and Speech" of the Academy of Sciences.

\section{Keywords:}

I.I. Sreznevsky, origins of Russian Slavistics, Slavic-Russian paleography, dialectology, education of pupils, the first doctor of Slavic-Russian philology.

Аннотация: Н.С. ГУСЕв. «У иСТОКОВ РОССИЙСКОЙ СЛАВИСТИКИ: СРЕЗНЕВСКИЙ И.И.».

Статья посвящена одному из основоположников российской славистики, Измаилу Ивановичу Срезневскому (1812-80). Начав научную карьеру с изучения славянского фольклора, ученый постепенно расширил сферу своих научных разысканий, написал очерк истории серболужицкой литературы, сконцентрировал свое внимание на южных славянах: их языках, древних литературах и палеографии древнеславянских рукописей. Преподавая славянскую филологию в Харьковском и Санкт-Петербургском университетах, он заложил основы таких научных славистических дисциплин, как диалектология, мифология и этнография, в 1846 г. стал первым доктором славяно-русской филологии и воспитал целое поколение блестящих ученых славистов За свои научные заслуги он был избран действительным членом Императорской академии наук и долгие годы был главным редактором «Известий Отделения русского языка и словесности» Академии наук.

\section{Ключевые слова:}

И.И. Срезневский, истоки российской славистики, Славяно-русская палеография, диалектология, воспитание учеников, первый доктор Славяно-русской филологии.

\footnotetext{
1 The work was carried out with the financial support of the RFBR (grant № 18-512-76004).
} 
Tmail Ivanovich Sreznevsky was one

of the founders of Russian Slavic studies, Slavic Russian paleography, dialectology, and a teacher who brought up a brilliant generation of Slavicists in the second half of the 19th century, the first doctor of Slavic-Russian philology.

He was born in Yaroslavl, the son of a professor in the department of Russian rhetoric and poetry at Kharkov University. At the age of 14, Sreznevsky entered the university in the faculty of law, graduating in 1829, and then, after defending his dissertation seven years later, began teaching in the department of political economy and statistics. However, since childhood he had been attracted to literature and folklore; he collected folklore

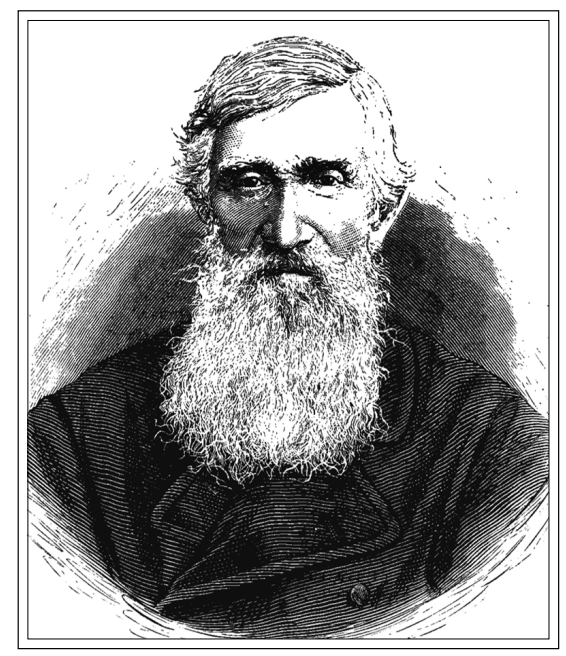

A Portrait of III. Sreznevsky, engraving, 1880 material and in his youth prepared the publication of the collections Ukrainian Almanac, Antiquity of Zaporozhie and Slovak Songs, which he recorded with Slovak merchants. His achievements were noticed, and in 1837 he was one of the first to be invited to go to the Slavic regions in preparation for the newly opened department of history and literature of Slavic dialects. His main focus was to be the practical study of languages, lifestyles, mores, customs and folklore, traveling around the country in the summer and engaging in library work in the winter.

In 1839 Sreznevsky left Kharkov. After travelling thorough German regions, where he met with venerable philologists and linguists, he arrived in Prague. There he struck up relationships with Pavel Jozef Shafárik, Josef Jungmann, Frantishek Chelakovsky and Frantishek Palatsky, and for many years was a close friend of Vatslav Hanka. During the same trip, the Russian scholar visited the Sorbs (Lusatian Serbs), having studied their language and everyday lives in detail. Thanks to his work The Historical Sketch of Serbo-Lusatian Literature, for many years he was rightly known to the masses to have discovered these peoples, and, as the Sorbs themselves admitted, he "provided advice and his own labor" in developing their national alphabet.

In 1841 Sreznevsky set off on a trip to the southern Slavs. His route lay through Slovakia, where he became friends with an ardent supporter of the independent Slovak language, Ludovit Shtur. Arriving in Lyublyana and then in Maribor, Sreznevsky began actively studying the language and folklore of the Slovenes, visiting coffee houses, taverns and bazaars. This and close interaction with local scholars allowed him to compile a very accurate and ground-breaking classification of Slovene dialects, published in the work On Slavic Dialects. 
Sreznevsky also visited Serbia, Croatia and Montenegro, but in the fall of 1842 he returned to Kharkov and took up a professorship.

In his lecture courses on the "Western Slavs of the northern and southern branches," which immediately gained popularity, he urged listeners to love and respect all Slavs, "because we are Slavs." During his years working in Kharkov, Sreznevsky partially processed the material collected on his trips and published articles in which he declared himself to be the founder of a number of Slavic disciplines in Russia (i.e., dialectology, mythology, ethnography). Contemporary seasoned scholars noted the young researcher's merits in the fields of ethnography and dialectology, and students were enthusiastic about his lectures. In 1846 Sreznevsky was the first in Russia to receive a doctorate in Slavic-Russian philology for his work Sanctuaries and rites of pagan worship of the ancient Slavs according to modern evidence and traditions. However, Sreznevsky's stay in Kharkov was disappointing for him due to students' lack of interest in issues related to the cultural revival of the southern and western Slavs.

In 1846, after the head of the Slavic department at St. Petersburg University passed away, Sreznevsky took over as its head. However, one could already sense the approach of the period of Russian history dubbed the "seven gloomy years" (1848-53) by contemporaries. In 1847 the Cyril and Methodius Society, based on democratic and pan-Slavic ideas, was forcibly shut down. The Ministry of Education issued a memorandum directing Slavic teachers to pay special attention to Russian studies and, on this basis, to instill patriotism in students.

Sreznevsky managed to adapt to the new conditions and in 1849 gave a brilliant lecture, Thoughts on the history of the Russian language and other Slavic dialects, where he outlined a new direction in his research, moving away from folklore and ethnographic research. From then on, Slavic studies took a backseat for him, though it didn't disappear from the scope of his scholar interests.

His course of lectures on Slavic studies also underwent changes. Previously, the language, literature, history, and ethnography of each nation were studied separately, but now the Slavs were considered as a whole, with the inclusion of the eastern Slavic branch: Russians, Ukrainians and Belarusians. Over time, Sreznevsky apparently began to cool toward teaching, as evidenced by students' rather conflicting memories of his performance. Linguistics as such, obviously, did not interest him - he "blossomed" in front of an audience when talking about Slavic literature, its main figures and about his trips to Slavic countries. At the same time, the scholar attracted his students to academic work; these included future writer Nikolay Chernyshevsky and future critic Nikolay Dobrolyubov, and a number of his students determined the shape of the next stage in the development of Slavic studies. These were the scholars Vladimir I. Lamansky, Peter A. Lavrovsky, Alexander Pypin, Vikenty Makushev, and Jan Baudouin de Courtenay. He encouraged his students to pay close attention to paleography, the science of the peculiarities of drawing written characters and how they changed, taught them how to use this in practice, and published a textbook on 
the subject. Contemporaries rightly considered him the best paleographer of the time.

Sreznevsky himself was then actively working on Old Russian and Old Slavonic manuscripts. He published reviews of ancient records of the Russian language, including written records and Yusovo writing, the language of the "southwestern Slavs," as well as Glagolitic documents, and he proved the Czech-Moravian origin of the Kiev Folios. Sreznevsky actively published ancient manuscripts, which contributed considerably to the creation of an academic base for the study of Old Slavic and ancient Slavic languages. The scholar's most ambitious work was the creation of a posthumously published three-volume dictionary of the Old Russian language.

Sreznevsky's academic achievements and talents were acknowledged by his election as a member of the Imperial Academy of Sciences and the Russian Geographical and Archaeological Societies, and he became editor of the Academy of Sciences' journal "Proceedings of the Department of Russian Language and Literature." In the pages of this journal, Sreznevsky published a large number of reviews and notes on the latest Slavic literature. From the mid-1850s to the mid-1860s, he wrote responses to 543 issues of the Proceedings. Sreznevsky's academic interests affected the choice of the works reviewed: the majority of the books concerned languages; a smaller part, the history and ethnography of the Slavs. Despite this, the journal served Slavists as a guide in the world of professional literature for many years. Although it was not possible to establish large-scale and systematic interaction with foreign academics, Pavel Jozef Shafárik, Florian Ceynova, Stefan Verkovich, and Bulgarians living in Russia such as Spiridon Nikolaevich $\mathrm{Pa}$ lauzov, Nayden Gerov and others took part in the journal.

At the same time, Sreznevsky's elevated position as dean of the Faculty of History and Philology required him to have a certain level of loyalty to the authorities. Sreznevsky lived up to his status, although he had held different

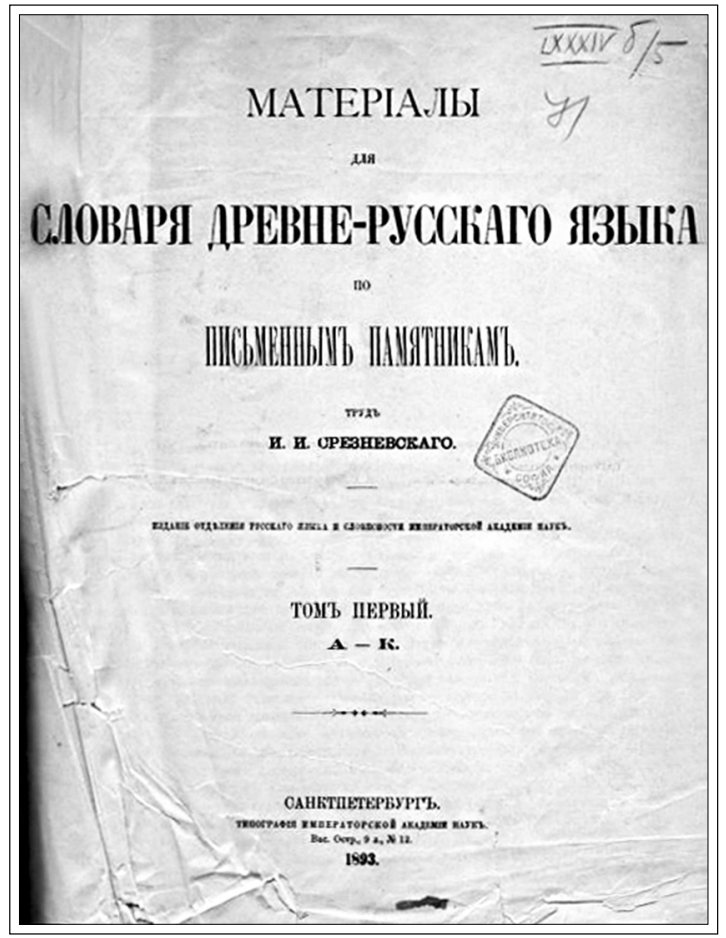

The First volume of II. Sreznevsky's work the "Materials for the dictionary of the Old Russian language on written monuments," published after the death of the scholar 
views in his youth. At that time he attached greater importance to the Ukrainian and Slovak languages, while in adulthood he argued that "there is no need to destroy or stop the writing of these dialects, but there is no need to make this writing independent, belonging as it were to a separate people." Over time he dissociated himself from the idea of Slavic reciprocity and the contribution of both large and small peoples to world culture, disapproving of those of his students who followed this paradigm. Democratic romanticism was something that was also lost from his worldview. Thus, as rector, Sreznevsky in 1861 supported the authorities' heavy-handed suppression of student unrest. His monarchical beliefs were apparently sincere, but Russia itself was changing, and in the era of the great reforms (1860-70s), many of his views already seemed archaic. For this reason, he was losing contact with the student audience.

A number of Sreznevsky's assertions subsequently turned out to be false, but even during his lifetime there were academic works that refuted his conclusions. He thus believed that the Cyrillic alphabet predated the Glagolitic alphabet, and until the end of his life he defended the authenticity of the Kraledvorsk and Zelenogorsk manuscripts. In the latter case, the scholar's friendship with the author of these fakes, Vátslav Hanka, apparently played a role.

After Sreznevsky's death, in accordance with his will, he was buried in the village of Sreznevo in Ryazan province, the place where his ancestors had served as parish priests for many years.

The academic's work was continued by his children. Three of them became philologists-specialists in the history of the Russian language, and two became corresponding members of the Academy of Sciences. Their contributions to science, of course, were inferior to those of their father. In addition to the previously mentioned achievements in the study of Old Slavonic and Old Russian written documents, Sreznevsky made valuable contributions to almost every country-specific branch of Slavic studies. The Bulgarian people welcomed his Essay on Printing in Bulgaria (1846), which characterized the state of Bulgarian literature. For Serbians, the biography of Vuk Karadzhich, the creator of the Serbian literary language (1846), is of great importance. Sreznevsky left the classification of the Slovenian language to the Slovenes $(1841,1845)$. His essays from 1846 and 1847 on Slavic literature (Literary revitalization of the Western Slavs and $A$ look at the current state of literature among the Western Slavs) retained their significance for a long time. He was a pioneer of the small Slavic nationalities: Friulian Rezian and Slovin, Zhumbor Uskoks. The majority of Sreznevsky's contributions to the Slavic heritage were achieved even before his move to St. Petersburg. However, in the capital's university, Sreznevsky actually laid the foundations for the future development of Slavistics. It was his students in the second half of the nineteenth century who, through their own works, declared his work to be among the highest achievements of pre-revolutionary Slavic studies.

Vladimir Lamansky, one of Sreznevsky's students with whom the teacher was not always on good terms, wrote in his obituary of the teacher: "One of the first 
advocates of Slavic studies in Russia, Sreznevsky will be remembered as one of the most gifted and remarkable Slavists in Europe. In the history of science and Slavic education, Sreznevsky's name will never die and will always be gratefully remembered by posterity."

Translated by Igor Kaliganov

\section{BIBLIOGRAPHY}

Bogatova GA. I.I. Sreznevskii. Moscow, 1985.

Dostal' M.Iu. I.I. Sreznevskii i ego rol' v istorii otechestvennogo slavianovedeniia // Slavianskii vestnik. Vyp. 2. Moscow, 2004.

Dostal' M.Iu. O nekotorykh spornykh momentakh v biografii I.I. Sreznevskogo // Slavianovedenie. 1992. N 2.

Lapteva L.P. Istoriia slavianovedeniia v Rossii v XIX veke. Moscow, 2005.

\section{ILLUSTRATIONS}

1. A portrait of I.I. Sreznevsky in his youth.

2. The collection "Zaporozhzhie antiquity" prepared by II. Sreznevsky.

3. A memorial plaque on the former library building of Kharkov University.

4. Published lecture by I.I. Sreznevsky's "Thoughts on the history of the Russian language."

5. The cover of I.I. Sreznevsky's publication "Tales of Saints Boris and Gleb."

6. The First volume of I.I. Sreznevsky's work "Materials for the dictionary of the Old Russian language on written monuments," published after the death of the scholar.

7. A photo of I.I. Sreznevsky during his years at St. Petersburg University.

8. Imprint of the article by I.I. Sreznevsky on the nationalities that he actually discovered - Friulian rezian and words.

9. The grave of I.I. Sreznevsky in the village of Sreznevo, Ryazan region. The inscription on the cross in Church Slavonic reads "Thy will be done."

10. A portrait of I.I. Sreznevsky, engraving, 1880. 